Vol. 4, No. 1, January 2016

Jurnal llmial

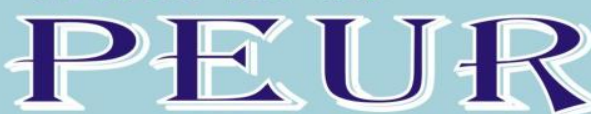

Media Kajian Ilmiah Sosial, Politik, Hukum, Agama dan Budaya
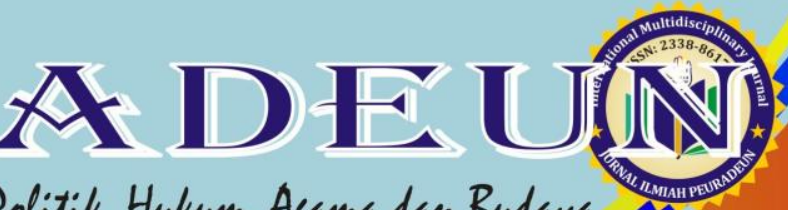


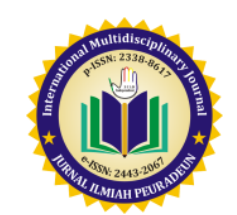

\title{
CHARACTER BUILDING OF STUDENTS BY GUIDANCE AND COUNSELING TEACHERS THROUGH GUIDANCE AND COUNSELING SERVICES
}

\author{
Nurhasanah and Qathrin Nida \\ Syiah Kuala University, Banda Aceh, Indonesia \\ E-mail: bunurhasanah1@gmail.com
}

Received: Apr 21, 2015

Accepted: Oct 5, 2015

Published: Jan 21, 2016

Article Url: https://journal.scadindependent.org/index.php/jipeuradeun/article/view/86

\begin{abstract}
This study aims to determine the process and counseling services performed by guidance and counseling (BK) teachers in coaching the students' character, with the method descriptive qualitative approach. Guidance and counseling are services of assistance given to students to develop their potential, alleviate the problems, and shape the character of the students in accordance with the norms that exist in the neighborhood. The character building of students can be done through guidance and counseling services that are prevention, alleviation and development. The results showed that the process of guidance and counseling was done not in accordance with established procedures and the implementation of observation and data identification to understand the needs within the framework of the preparation of BK program. Besides, the prevention activities were carried out by providing knowledge about the character of the students through information services, content mastery and group counseling as well as involving students in religious activities at school.
\end{abstract}

Keywords: Character building of students, guidance and counseling services. 


\section{A. Introduction}

Guidance and Counseling (BK) is an integral part of education. Each element of the education aims to develop intellectual abilities and shape the character. In accordance with the formulation of Law Number 20 of 2003 on National Education System, that education function to develop skills and character building as well as the civilization and dignity in the context of the intellectual life of the nation, aimed at developing students' potentials in order to become a human of faith and fear of God Almighty, noble, healthy, knowledgeable, capable, creative, independent, and become citizens of a democratic and responsible.

Schools are institutions of formal education in which teachers play a role of educating, guiding and shaping (building) the character of the students in accordance with the rules of the norm to be personal morality (character). The character building of students become primary responsibility for teachers in the school, parents at home, and people in the neighborhood.

Looking at the various phenomena that happen on students today are very concerned about even very disturbing government, communities, parents, and even teachers so that character education curriculum is developed and applied in the education unit. However, the fact that it looks today is far from the desired expectations. The character of the folk nation is getting out of control, like smoking, defying parents and teachers, do not respect the teacher, do not assume the responsibilities as students and less concerned with the condition themselves and the surrounding environment, they do something beyond the limits of reasonableness even violate the established norms and Shari'ah.

The influence of foreign cultures has decreased religious values and the values of decency simultaneously. Excessive appearance due to follow the trend of foreign cultures and being far from decency are adopted by the students. The condition of the students is not currently oriented on the future. This can be seen when students ignore the responsibility as a student at the school, neglect of duty, does not obey the rules, cheating when exams, even some students to school just wants to get a certificate of graduation without having to think about and plan for the future. All phenomenons happened requires serious attention from the government, parents, communities, and teachers, especially BK teachers. 
BK Teacher is a friend of the students at the school and also teachers assigned to develop the potential of the students in accordance with its development and help realize the goal of education expected. The educational goals can be realized through intensive, effective, efficient and sustainable counseling. Based on preliminary studies in school, there are BK teachers who do counseling process that is not in accordance with established procedures. The counseling process is carried out only in the form of advisory and punishment for students, who make mistakes, rarely has BK teachers seen to apply the guidance and counseling services to alleviate problems experienced by students.

\section{B. Literature Review}

\section{Description of Character Development}

The character building of students is the effort made by teachers in order to establish the character of the students. Currently in Indonesia, it is being promoted formation of school culture. One of the chosen school culture is the culture of noble character, known as character education. From this, the term establishment of culture of noble character in school is introduced. Therefore, teachers in schools including the BK teachers and other school staff together improve the quality of learning in schools. One of the efforts that can be done is the build the character of students through guidance and counseling services carried out by the BK teachers. The BK teachers need to design and implement a service program and guidance and counseling services in the classroom and outside the classroom that can facilitate students to familiarize good or noble character. Likewise with other subject teachers they can associate learning materials with inculcating the values of character in students.

\section{The purpose and function of Character Building}

The character building can improve the quality of the implementation and results of school education that leads to the achievement of the formation of character and noble character of learners as whole, integrated, and balanced, appropriate competency standards. Through character development, it is expected that learners are able to increase and use the knowledge independently, study, personalize the values of character and noble character so manifest in everyday behavior. 


\section{Role and Function of Guidance and Counseling Teacher in Building Character of Students}

The existence of counselors in the national education system is declared as one of the qualifications of educators, parallel to the qualifications of teachers, teacher mentor, lecturers, tutors, instructors, facilitators and other designations that are in accordance with the specialization and participation in education. Based on the position alignment, counselor (tutor) has the same function in achieving national education goals. The teacher mentor is very important role in character building of students, therefore, to establish and build character expected, it is needed a teacher mentors who has the competence and characteristics as a counselor.

The roles of the teacher mentor/ counselor at school to build the character of students are to; (A) identify the student and the problem, (b) plan BK program in accordance with the needs of students, (c) keep a record of students, (d) cooperate with the school, (d) implement BK services according to the needs and concerns of students, (e) carry out individual counseling or group counseling to alleviate the problem of students, (f) conducting personal development of students, (g) evaluating, (h) carry out follow-up, and (i) carry case conferences, home visits and hand over case if needed.

\section{Process of Guidance and Counseling in the Student Character Building}

The concept of "process" is used widely in the discussion about what actually happen in counseling. Although there are several meanings of the "process", but all refer to an understanding of the changes, movements and activities in counseling (McLeod, 2008: 391). Thus the counseling process is a series of activities or events which happen during counseling sessions between the counselor and counselee in several phases and stages that have been established, namely the initial, the middle and the end phase, where in each of these there are several stages and techniques performed by the counselor to explore the problems faced by the counselee during the counseling process. In order to build the character of students, it is carried out through guidance and counseling services, guidance counselor does the process in accordance with the stages or procedures that have been 
established. Tohirin (2007: 317) suggests several steps that can be done by counselors in the counseling process to alleviate the problem of students, that is; (A) define the problem, (b) the collection of data, (c) data analysis, (d) diagnosis, (e) prognosis, (f) evaluation and follow-up.

\section{Implementation of Guidance and Counseling Services in coaching Character of the Students}

The guidance and counseling services are key to the guidance counselor (BK teachers) in providing services to students at school. In character building activities at school, guidance counselor should facilitate the building and growth of character, therefore, the guidance counselor should design counseling programs and carry out activities and participate actively in the development, growth and habituation of character on students. Such activities can be carried out independently and designed in counseling and guidance programs in collaboration with other educators (subject teachers, homeroom and principals). Relating to these activities, counseling services can be preventive (prevention), curative (reduction) and developmental (development). The preventive service means activities carried out by a guidance counselor (BK teacher) to prevent the students' behavior in contrast to the expected characters. The curative service means that the service is carried out by a guidance counselor who aimed to alleviate the problems or cure the students' behaviors that violate the expected character. Meanwhile the developmental service is provided by the guidance counselor with the purpose of maintaining and developing the well-behaved students' character to keep as it is, not violate the norms and develop it to be better.

\section{Research Method}

The approach used in this study is a qualitative approach, in which this approach is a research procedure that produces descriptive data in the written or spoken form of the people and observed behavior, an approach that describe or examine more deeply a situation exists in the field with a view to know the character building of students by the BK teachers through the implementation of guidance and counseling services. This type of 
research is qualitative descriptive to gather various information about phenomena that are in the field of research. With this approach, it will be easier for the author to express, analyze and interpret the data/ information regarding research about character building of students described with the form of words/ descriptions, in a systematic, precise, effective and efficient and explained in accordance with the data/ information obtained by researcher in the study.

This research was conducted at State Senior High School 01 (SMA Negeri 1) of Sibreh, Aceh Besar regency. This school was chosen as field of research because the schools run the counseling in accordance with the procedure counseling and character education curriculum that has been set. This can be seen in the implementation of daily learning activities by teachers who implement character education lesson and guidance and counseling teachers who nurture students in accordance with character education. The subjects of this study were the teacher of guidance and counseling (BK teacher), the principal and subject teachers. Data collection techniques performed by the authors in this study were the observation, documentation and interview with the respondent/ informant.

\section{Research Finding and Discussion}

Based on the research results, it can be analyzed that the character building of students conducted by BK teacher through guidance and counseling services at SMA Negeri 1 Sibreh of Aceh Besar was relatively good. That is, the counseling teachers in cooperation with principals, subject teachers and other school staff have been working to establish and build the character of students in accordance with the applicable norms both within the school and in society.

\section{Guidance and Counseling Process conducted by BK Teacher to Build Students' Character.}

a. Process of Guidance and Counseling in the Prevention Activity.

Process of counseling and guidance is related to prevention activities and the preparation of guidance counseling program. Initially, the BK teachers will identify the needs of students. The Steps taken for identification of student needs were done by the BK teachers by using a predictive approach that was 
assumptive that only predicts the needs of students with a look and pay attention to the development and problems of students at the school. The BK teachers also conducted interviews with the students and did the observation when entering the classroom by asking questions related to what was required by students in the context of the development. The BK teachers stated that they ever gave the aptitude test to determine students' potential and to determine the needs of students in the framework of the preparation of guidance and counseling program, but the BK teachers did not show the results of aptitude tests when they were interviewed.

\section{b. Process of Guidance and Counseling in Alleviation Activity.}

Based on the results of studies related to the process of guidance and counseling to build the character of students, especially in alleviating the problem the $\mathrm{BK}$ teachers seeking information initially about the students and information regarding problems faced by students. If the students are students who are pointed by the subject teachers or homeroom teacher, the BK teacher will find out more information from the subject teachers or homeroom teacher related problems experienced by students (counselee). But, if the students' are the students who are called by the BK teachers to do the counseling process, the BK teacher will explore the problems experienced by these students when the counseling process takes place. The students who violate school rules such as coming late to school, fence jumping, and outside class during school hours will be called into the guidance and counseling room to do the counseling process. The BK teacher will ask the student the causes of late for school and students will usually respond because they oversleep or assist parents in advance at home. So it is also with the students who jump the fence of the school and do not go to class during the hours of lessons, teachers BK will ask the same thing that causes students to do this and to further the BK teachers perform troubleshooting alternatives.

Based on the recognition of the BK teachers in schools, they have difficulty to apply counseling process in accordance with the procedure while the process is underway, handling between one student and other students could be different. The differences is intended because the students are so 
easily led when to look for alternative solutions in the counseling process, but there are also students who are so difficult to give the direction and rely entirely to the solutions given by the BK teacher, so the counseling process is carried out as advisory. Students who repeatedly make problems in school such as constantly violating discipline, even do not attend school every day and always get counseling services but does not show the change, then the students will be directly handled by the principal. The principal will give time for three days to see the changes in students, but if nothing changes, then these students will be dropped out from school.

\section{Implementation of Guidance and Counseling Services for Building Students' Character.}

Prevention activities were carried out by identifying the data on students by distributing a book in the form of report cards for the necessary data regarding the student's personal, concerning the conditions themselves, their families and the environment. The BK teachers also make notes on students by seeing and observing the development, problems and changes in the student while in school. The data about the student were used by the BK teacher for the preparation of guidance and counseling program. In addition, the BK teachers also found a variety of information that was being developed to be delivered to students through counseling services. Before implementing the counseling program, the BK teacher first convey to the principal about the planned program that would be implemented, including the necessary infrastructure. After having approval from the principal, the BK teachers also convey to the other teachers who were in schools to improve the cooperation and support plans that have been programmed.

The prevention activities undertaken by the BK teachers related to character building of students were:

a. To give knowledge about the characters through information services, such as the formation of self-discipline in students.

b. To form self-confidence in students, this was implemented through the control service content, which was then followed by group counseling services to train students' self-confidence through socialization and communication within the group dynamic atmosphere. 
c. To supervise the students to improve the tidiness and concern for self, family, community and school environments.

d. To direct and familiarize the students to help each other and appreciate each other as well as develop politeness character.

e. To provide spiritual cleansing to the student after the noon prayer in schools by inviting teungku(religious teacher) so instilling religious values on students.

\section{Alleviation Activity}

The implementation of reduction or improvement for character building of students conducted by the BK teacher at school is related to the way in which the BK teacher in alleviating problems faced by the students, especially in the conditioning and direction of positive behaviors and in accordance with the norm for the students so that students have the expected character. The services performed by the BK teachers in reduction activities were:

a. To carry out individual and group counseling services in accordance with students' problems.

b. To carry out support activities of counseling that includes home visits, hand over the case and case conferences if necessary.

c. To implement and follow-up evaluation and counseling process that has been undertaken to see the changes on students.

\section{Development Activities}

The development activities is one form of activity in the direct counseling services and developing various potential and become student with a better behavior, maintain and develop behavior optimally. The form of character that needs to be developed is:

a. Developing discipline and self-confidence, as well as raise awareness and manners.

b. Engaging students in extracurricular activities and scouting activities.

c. Increasing the self-development of students by organizing various competitions through student council activities.

d. Coaching talent interests through extracurricular activities. 


\section{E. Conclusion.}

The process of counseling is conducted by the BK teachers to build students' character and alleviate problems identifying the problems of the students and look for more in-depth information on students. The counseling process is carried out in accordance with the characteristics of the student's personality and in accordance with the problems faced by students, but not based on established procedures in guidance and counseling services so that the counseling process undertaken tend to like giving advice to students. The cooperation among the BK teachers, subject teacher, homeroom teacher and the principal goes well, although sometimes troubled students handled directly by the principal without involving the BK teachers. However, an outline of the counseling process in the activities undertaken to alleviate the problem of students is good enough and sufficient because after getting the counseling services, the students showed a better change.

The process of counseling associated with stages carried out by the BK teachers before drafting guidance and counseling program is not based on identifying the actual and objective needs of students, but the BK teachers only predict assumptive to the needs of students in the school. Thus, programs of guidance and counseling services are not fully fit to the needs and problems of students in the school.

The activities of counseling services implemented to build students' character at school are prevention, alleviation and development. The activities of preventative services are done by identifying data first about the students and make a note of the students, arrange counseling program, provide knowledge about the values of character, carry out information services, content mastery service and the group service involved in the activities of students in the orientation of students, student organizations and religious activities. The activities of alleviation service are carried out by the students identify problems, implement individual counseling and group counseling, case conferences and home visits when necessary, and to evaluate the service and follow-up activities of the student changes. The Development activities are carried out by developing the character values through mastery of content services and group counseling services, but the BK teachers do not fully involved in extracurricular activities for the development 
of students. The development activities are also carried out by inviting in other parties outside of the school for students' character building, and working with subject and homeroom teachers to carry out activities that support the development of students.

\section{Bibliography}

Departemen Pendidikan Nasional. (2012). Kamus Besar Bahasa Indonesia, Edisi ke-empat. Jakarta: Gramedia.

Eliasa, E. I. 2012. Peran Bimbingan dan Konseling dalam Pendidikan Karakter Siswa. UNY. (http://himcyoo.files.wordpress.com/2012/04/.pdf) diakses tanggal 24 Juli 2013

Kementerian Pendidikan Nasional. (2010). Buku Pedoman Pendidikan Karakter di Sekolah Menengah Pertama. Jakarta: Direktorat Jendral Mandikdasmen, Direktorat Pembinaan Sekolah Menengah Pertama.

Kementerian Pendidikan Nasional. (2010). Kerangkan Acuan Pendidikan Karakter Kementerian Pendidikan Nasional Tahun 2010. Jakarta: Direktorat Jenderal Pendidikan Tinggi, Direktorat Ketenangan.

Kertamuda, E. F. (2012). Peran Konselor Sekolah dalam Pembentukan Karakter Siswa. Jakarta: Universitas Paramadina. (http://publikasiilmiah.usm.ac.id/) diakses tanggal 20 Agustus 2013.

Maleong. (2005). Metode Penelitian Kualitatif. Jakarta: Rineka Cipta.

McLeod, J. (2008). Pengantar Konseling dan Studi Kasus. Jakarta: Kencana.

Prayitno. (2004). Seri Layanan Konseling. FIP Universitas Negeri Padang.

Redjeki, Sri. (2013). Pengembangan Karakter Melalui Pelayanan Bimbingan dan Konseling. Majalah Ilmiah Pawiyatan, Vol: XX, (3): 47-57.

Salami, S. (2015). Implementing Neuro Linguistic Programming (NLP) in Changing Students' Behavior: Research Done at Islamic Universities in Aceh. Jurnal Ilmiah Peuradeun, 3(2), 235-256.

Tohirin. (2007). Bimbingan dan Konseling di Sekolah Madrasah. Jakarta: PT Raja Grafindo Persada.

Tohirin. (2012). Metode Penelitian Kualitatif dalam Pendidikan Bimbingan Konseling. Jakarta: PT Raja Grafindo Persada.

Undang-undang Republik Indonesia Nomor 20 Tahun 2003 Tentang Sistem Pendidikan Nasional. 
Yusoff, M. Z. M., \& Hamzah, A. (2015). Direction of Moral Education Teacher To Enrich Character Education. Jurnal Ilmiah Peuradeun, 3(1), 119-132.

ZA, T. (2014). Islamic Studies dalam Pendekatan Multidisipliner (Suatu Kajian Gradual Menuju Paradigma Global). Jurnal Ilmiah Peuradeun, 2(2), 211-234. 